JURNAL ILMIAH KOMPUTERISASI AKUNTANSI, Vol. 14, No. 2, Desember 2021, pp.383 - 393

p-ISSN : 1979-116X (print)

e-ISSN : $2614-8870$ (online)

http://journal.stekom.ac.id/index.php/kompak

page 383

\title{
ANALISA NILAI TUKAR PETANI DI PROVINSI RIAU
}

\author{
Rezi Abdurrahman', Lukman Hakim² \\ ${ }^{1}$ Universitas Riau \\ e-mail: rezi.abdurrahman@lecturer.unri.ac.id \\ ${ }^{2}$ Sekolah Tinggi Ilmu Ekonomi Syariah Bengkalis \\ e-mail: Lukman_hakim94@ymail.com
}

\section{ARTICLE INFO}

Article history:

Received 30 September 2021

Received in revised form 2 November 2021

Accepted 10 November 2021

Available online 1 Desember 2021

\section{ABSTRACT}

This study was conducted to determine the factors that influence the farmer's exchange rate (the ratio of the price index received by farmers to the price index paid by farmers) in the food crops sub-sector in Riau Province. The data collected in this study is data published by the Central Statistics Agency of Riau Province. The data obtained were then analyzed using SPSS 22. The test results show that the level of expenditure has a negative and significant effect on the exchange rate of farmers in the food crop sub-sector, this can be seen from the value of tcount $(-2.475)<$ ttable $(2.44691)$ with a significant value of $0.048<0.05$. Harvested area has a significant positive effect on the exchange rate of farmers in the food crop sub-sector, this can be seen from the value of tcount $(4.441)<$ ttable $(2.44691)$ with a significant value of $0.004<0.05$. Meanwhile, the food import variable has no significant effect on the exchange rate of farmers in the food crop subsector, this can be seen from the value of tcount $(2.273)<$ ttable $(2.44691)$ with a significant value of $0.063>0.05$, with a value of Fcount (12.476) > Ftable , (4,35).

Keywords: Farmer's Exchange Rate, Food Crops Subsector.

\section{Introduction}

Hakekat dari pembangunan pertanian yaitu bertujuan untuk meningkatkan kesejahteraan masyarakat sektor pertanian. Sektor pertanian merupakan sektor perekonomian berbasis sumber daya lokal yang mempunyai peran yang cukup besar terhadap pembangunan suatu negara khususnya negara berkembang seperti Indonesia (Nirmala, 2016).

Nilai Tukar Petani (NTP) adalah perbandingan atau rasio antara indeks harga yang diterima petani dengan indeks harga yang dibayar petani. Nilai tukar petani ini berkaitan dengan hubungan antara hasil pertanian petani dengan barang dan jasa yang dikonsumsi dan dibeli oleh petani. Indeks harga yang diterima petani adalah indeks harga yang menunjukkan perkembangan harga produsen atas hasil produksi petani. sedangkan indeks harga yang dibayar petani adalah indeks harga yang menunjukkan perkembangan harga kebutuhan rumah tangga petani, baik untuk kebutuhan konsumsi rumah tangga maupun kebutuhan untuk proses produksi pertanian (Riau, 2017). 
Besarnya pendapatan dari off-farm dipengaruhi oleh kesempatan/peluang berusaha dan tingkat upah. Tingkat pendapatan non farm juga dipengaruhi oleh aset dan kemampuan untuk dapat akses terhadap layanan, iklim usaha, produktivitas usaha dan harga produk yang dihasilkan (Nono Rusono, 2013). Berdasarkan penelitian Hendayana pada tahun 2002 Peningkatan NTP sebesar $1 \%$ akan meningkatkan produksi $0,02 \%$, dan peningkatan NTP sebesar 1 point akan meningkatkan pendapatan Rp 1.285,8. Jadi meningkatnya NTP dapat dilihat dari produksi dan pendapatan akan meningkatkan kesejahteraan petani.

Beberapa faktor yang menentukan nilai tukar petani menurut Rahmat tahun 2002 yaitu: Pertama, Nilai Tukar Petani terhadap Konsumsi Makanan (NTP-Mak). Nilai tukar ini menggambarkan daya beli masyarakat terhadap harga produk makanan yang dibeli petani. Produk konsumsi makanan mencakup padi-padian, daging-ikan-unggas, sayur-sayuran, usu-telur-lemak, buah-buahan, dan kelompok makanan minuman lainnya. Kedua, Nilai Tukar Petani terhadap Konsumsi Nonmakanan (NTP-NMak). Nilai tukar ini menggambarkan daya beli masyarakat terhadap harga produk non-makanan yang dibeli petani. Perkembangan harga-harga produk nonmakanan merupakan harga yang terbentuk dari pengeluaran untuk perumahan, tempat tinggal, dan aneka jenis barang dan jasa..

Ketiga, Nilai Tukar Petani terhadap Biaya Produksi (NTP-BP). Nilai tukar ini menggambarkan daya beli antara komoditas yang dihasilkan petani terhadap biaya produksi. Komponen biaya produksi dikelompokkan dalam input pupuk, tenaga kerja, dan input modal kerja lainnya. Ekspektasi laju inflasi, apalagi jika disertai kenaikan harga BBM, akan menambah biaya pengeluaran masyarakat, tidak terkecuali petani. Ukuran yang paling kasar seperti nilai tukar petani pun telah menunjukkan kecenderungan memburuknya kesejahteraan petani. Selain inflasi, pemerintah Indonesia juga kerap melakukan impor, terutama dibidang pangan, berdasarkan data Badan Pusat Statistik pada tahun 2017 impor beras mencapai 305 274,6 ton. Badan Pusat Statistik (BPS) mencatat pemerintah Indonesia telah melakukan impor beras sebanyak 2,25 juta ton dengan nilai US\$ 1,03 miliar disepanjang tahun 2018. Dari total 2,25 juta ton beras impor, pada Januari masuk sebesar 13,17 ribu ton dengan nilai US\$ 5,80 juta. Pada Februari masuk sebanyak 272,89 ribu ton dengan nilai US\$ 130,08 juta. Pada Maret masuk sebanyak 97,63 ribu ton dengan nilai US\$ 44,73 juta.

Nilai tukar petani (NTP) Riau agustus 2016 mengalami kenaikan sebesar 0,58\% dibandingkan bulan sebelumnya. Nyatanya, nasib petani pangan masih bersedih. Pasalnya NTP subsektor tanaman pangan seperti padi dan palawija mengalami penurunan sebesar $0,17 \%$. Adapun sector tanaman pangan meliputi padi dan palawija. Sementara Berdasarkan hasil pemantauan harga-harga perdesaan di Provinsi Riau, Nilai Tukar Petani (NTP) di Provinsi Riau pada Oktober 2018 sebesar 94,73 atau turun sebesar 1,46 persen dari sebelumnya. Hal ini disebabkan harga barang/produk pertanian yang dihasilkan oleh rumah tangga mengalami penurunan, sementara harga barang dan jasa yang dikonsumsi oleh rumah tangga maupun untuk keperluan produksi mengalami kenaikan.

Tabel. 1

\section{Nilai Tukar Petani Subsektor Tanaman Pangan Provinsi Riau Tahun 2008-2017}

\begin{tabular}{|c|c|c|c|}
\hline No & TAHUN & NTTP & Arti angka/Keterangan \\
\hline 1 & 2008 & 103,21 & Surplus \\
2 & 2009 & 103,77 & Surplus \\
3 & 2010 & 110,52 & Surplus \\
4 & 2011 & 112,63 & Surplus \\
5 & 2012 & 113,60 & Surplus \\
\hline
\end{tabular}

JURNAL ILMIAH KOMPUTERISASI AKUNTANSI Vol. 14, No. 2, Desember 2021 : 383 - 393 


\begin{tabular}{|c|c|c|c|}
6 & 2013 & 109,66 & Surplus \\
7 & 2014 & 100,44 & Surplus \\
8 & 2015 & 103,67 & Surplus \\
9 & 2016 & 102,63 & Surplus \\
10 & 2017 & 104,00 & Surplus \\
\hline
\end{tabular}

Sumber : Badan Pusat Statistik Provinsi Riau

\section{Research Method}

\subsection{Populasi Dan Sampel}

Dalam metode penelitian kata populasi digunakan untuk menyebutkan serumpun atau sekelompok objek yang menjadi sasaran penelitian.

Populasi penelitian merupakan keseluruhan (universum) dari objek penelitian yang dapat berupa manusia, hewan, tumbuh-tumbuhan, udara, gejala, nilai, peristiwa, sikap hidup dan sebagainya. Sehingga objek-objek ini dapat menjadi suber data. Populasi pada penelitian ini adalah data Nilai Tukar Petani di Provinsi Riau.

Sampel adalah sebagian atau wakil populasi yang diteliti. Ataupun bagian kecil dari anggota populasi yang diambil menurut prosedur tertentu sehingga dapat mewakili populasinya. Sampel yang diambil dari penelitian ini adalah data publikasi BPS mengenai Nilai Tukar Petani Subsektor Tanaman Pangan dari tahun 2008-2017.

\subsection{Teknik Pengumpulan Data}

Metode pengumpulan data adalah bagian instrumen pengumpulan data yang menentukan berhasil atau tidaknya suatu penelitian.

Teknik pengumpulan data didalam penelitian ini adalah dokumentasi. Metode pengumpulan dokumentasi adalah mencari data mengenai hal-hal atau variabel yang berupa catatan, transkip, buku, surat kabar, majalah, dan lain sebagainya. Dalam penelitian ini dilakukan pengumpulan data dengan data yang telah dipublikasikan oleh Badan Pusat Statistik.

\subsection{Teknik Analisa Data}

Metode analisa data adalah suatu metode yang digunakan untuk mengolah hasil penelitian guna untuk memperoleh kesimpulan. Termasuk alat-alat statistik yang relavan untuk digunakan dalam penelitian. (Sujarweni, 2016). Kegiatan dalam analisis data adalah mengelompokan data berdasarkan variabel dan jenis responden, mentabulasi data berdasarkan variabel dari seluruh responden, menyajikan data tiap variabel yang diteliti, melakukan perhitungan untuk menjawab rumusan masalah dan melakukan perhitungan untuk menguji hipotesis yang telah diajukan (Siregar, 2015)

Metode analisa dalam penelitian ini mengguanakan pengujian statistik. Statistik merupakan metode dan aturan-aturan untuk mengumpulkan, mengolah, menyajikan, dan menganalisa serta menginterpretasikan data yang akhirnya akan digunakan untuk mengambil keputusan Dan penelitian mengolah data menggunakan SPSS versi 22 dengan metode analisis yang digunakan adalah:

\section{a. Statistik Deskriptif}

Analisis statistik deskriptif digunakan untuk menggambarkan karakter suatu kelompok, sampel atau data. Analisis statistik deskriptif ini hanya berlaku ditingkat sampel sehingga tidak bisa digunakan untuk membuat simpulan yang lebih luas (generalisasi).

\section{b. Uji Asumsi Klasik \\ 1. Uji Normalitas}


Uji normalitas data ini bertujuan untuk mengetahui distribusi data dalam variabel yang akan digunakan dalam penelitian. Data yang baik dan layak digunakan dalam penelitian adalah data yang memiliki distribusi normal. Normalitas data dapat dilihat dengan menggunakan uji Normalitas Kolmogorov-Smirnov. Pengambilan kesimpulan dapat dilihat dari :

Jika sig $>0,05$ maka data berdistribusi normal.

Jika sig $<0,05$ maka data tidak berdistribusi normal

\section{Multikolinieritas}

Uji Multikolinieritas digunakan untuk mengetahui ada tidaknya variabel independen yang memiliki kemiripan antar variabel independen dalam satu model. Kemiripan antar variabel independen akan mengakibatkan korelasi yang sangat kuat. Selain itu untuk uji ini juga untuk menghindari kebiasaan dalam proses pengambilan keputusan menengenai pengaruh pada uji parsial masing-masing variabel independen terhadap variabel dependen.

\section{c. Regresi Linear Berganda}

Regresi linear berganda digunakan untuk mengetahui pengaruh variabel bebas (Independen) terhadap variabel terikat (dependen). Regeresi berganda merupakan perluasan dari regresi sederhana dengan dua atau lebih variabel bebas yang digunakan sebagai prediktor dan satu variabel tergantung yang diprediksi. Model persamaan regresi berganda sebagai berikut:

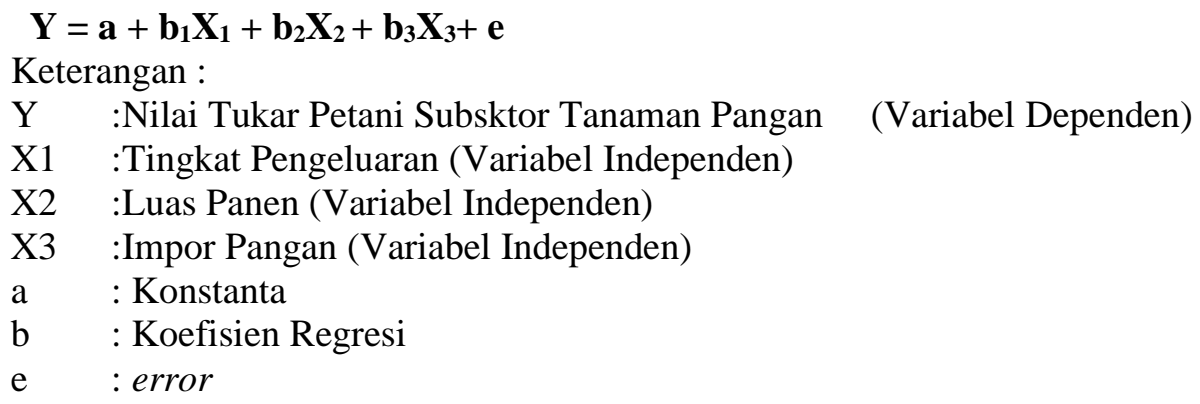

\section{d. Uji Parsial (Uji t )}

Pengujian ini bertujuan untuk menunjukkan seberapa jauh pengaruh satu variabel dengan variabel penjelas atau independen secara individual dalam menerangkan variasi indepeden.

Untuk melihat pengaruh variabel independen terhadap dependen, uji t dilakukan dengan membandingkan nilai thitung dangan ttabel

Kriteria ujinya, yaitu :

- $\quad$ Jika thitung < ttabel maka Ha ditolak

- $\quad$ Jika thitung > ttabel, maka Ha diterima

Berdasarkan signifikansi :

- $\quad$ Jika signifikansi $>0,05$, maka Ha ditolak

- $\quad$ Jika signifikansi $<0,05$, maka Ha diterima

e. Uji F (Simultan)

Pengujian ini dilakukan untuk mengetahui pengaruh dari dua variabek independen atau lebih secara simultan (bersama) terhadap variabel dependen. Dasar pengambilan keputusan dalam Uji F adalah :

JURNAL ILMIAH KOMPUTERISASI AKUNTANSI Vol. 14, No. 2, Desember 2021 : 383 - 393 
1) Jika nilai $F$ hitung > F tabel maka variabel independen (bebas) secara simultan berpengaruh terhadap variabel depeden (terikat).

2) Jika nilai $F$ hitung < $F$ tabel maka variabel independen (bebas) secara simultan tidak berpengaruh terhadap variabel depeden (terikat).

Berdasarkan nilai signifikan :

1) Jika nilai signifikan $<0,05$, maka variabel indepeden secara bersama-sama berpengaruh signifikan terhadap variabel dependen.

2) Jika nilai signifikan >0,05, maka variabel indepeden secara bersama-sama tidak berpengaruh signifikan terhadap variabel dependen.

f. Uji Koefisien Determinan $\left(\mathrm{R}^{2}\right)$

Koefisien determinan (R2) pada intinya mengukur seberapa besar kontribusi berpengaruh variabel independen terhadap variabel terikat. Dengan syarat hasil uji $\mathrm{F}$ dalam analisis regresi bernilai signifikan. Sebaliknya, jika hasil dalam Uji F tidak signifikan maka nilai koefisien determinan (R2) ini tidak dapat digunakan untuk memprediksi kontribusi pengaruh variabel $\mathrm{X}$ terhada Y (Pratisto, 2016)

\section{Results and Analysis}

1. Hasil Statistik Deskriptif

Tabel.2

Statistik Deskriptif

Descriptive Statistics

\begin{tabular}{|l|r|r|r|r|r|}
\hline & \multicolumn{1}{|c|}{$\mathrm{N}$} & \multicolumn{1}{c|}{ Minimum } & Maximum & \multicolumn{1}{c|}{ Mean } & Std. Deviation \\
\hline NTPP & 10 & 2.00 & 2.06 & 2.0266 & .01901 \\
Tingkat Pengeluaran & 10 & 5.63 & 6.00 & 5.8280 & .12952 \\
Luas Panen & 10 & 1.05 & 3.03 & 1.9328 & .70542 \\
Impor Pangan & 10 & 5.40 & 6.44 & 5.8524 & .35151 \\
Valid N (listwise) & 10 & & & & \\
\hline
\end{tabular}

Dari tabel diatas dapar di interprestasikan statistik deakriptif dari variabel-variabel dalam penelitian ini adalah sebagai berikut :

a. Nilai Tukar Petani Subsektor Tanaman Pangan (NTPP)

Berdasarkan pengujian statistik diatas, dapat dilihat nilai minimum sebesar 2.00 dan nilai maksimum sebesar 2.06, serta nilai rata-rata (mean) sebesar 2.0266 dengan standar deviasi sebesar 0.01901. nilai rata-rata (mean) 2.0266 yang menunjukkan bahwa besarnya nilai tukar petani subsektor tanaman pangan sebesar 2.0266 artinya terdapat penyebaran data yang baik karena nilai rata-ratanya lebih besar dari pada standar deviasinya.

b. Tingkat Pengeluaran

Berdasarkan pengujian statistik diatas, dapat dilihat nilai minimum sebesar 5.63 dan nilai maksimum sebesar 6.00, serta nilai rata-rata (mean) sebesar 5.8280 dengan standar deviasi sebesar 0.12952. nilai rata-rata (mean) 5.8280 yang menunjukkan bahwa besarnya tingkat pengeluaran sebesar 5.8280 artinya terdapat penyebaran data yang baik karena nilai rata-ratanya lebih besar dari pada standar deviasinya.

c. Luas Panen

Berdasarkan pengujian statistik diatas, dapat dilihat nilai minimum sebesar 1.05 dan nilai maksimum sebesar 3.03, serta nilai rata-rata (mean) sebesar 1.9328 dengan standar deviasi sebesar 0.70542. nilai rata-rata (mean) 1.9328 yang menunjukkan bahwa besarnya 
luas panen sebesar 1.9328 artinya terdapat penyebaran data yang baik karena nilai rataratanya lebih besar dari pada standar deviasinya.

d. Impor Pangan

Berdasarkan pengujian statistik diatas, dapat dilihat nilai minimum sebesar 5.40 dan nilai maksimum sebesar 6.44, serta nilai rata-rata (mean) sebesar 5.8524 dengan standar deviasi sebesar 0.35151. nilai rata-rata (mean) 5.8524 yang menunjukkan bahwa besarnya luas panen sebesar 5.8524 artinya terdapat penyebaran data yang baik karena nilai rataratanya lebih besar dari pada standar deviasinya.

\section{Uji Asumsi Klasik}

a. Uji Normalitas

Uji normalitas data ini bertujuan untuk mengetahui distribusi data dalam variabel yang akan digunakan dalam penelitian. Uji normalitas data yang digunakan dalam penelitian ini menggunakan Uji One Sample Kolmogorov-Smirnov (Uji K-S) dan analis grafik (Normal P-Plot) regresi. Haisil Uji One Sample Kolmogorov-Smirnov (Uji K-S) dapat dilihat pada tabel dibawah ini :

Tabe 3. Uji Normalitas

\begin{tabular}{|c|c|c|}
\hline \multicolumn{3}{|c|}{ One-Sample Kolmogorov-Smirnov Test } \\
\hline & & $\begin{array}{l}\text { Unstandardiz } \\
\text { ed Residual }\end{array}$ \\
\hline $\mathrm{N}$ & & 10 \\
\hline \multirow[t]{2}{*}{ Normal Parameters ${ }^{\mathrm{a}, \mathrm{b}}$} & Mean & .0000000 \\
\hline & $\begin{array}{l}\text { Std. } \\
\text { Deviation }\end{array}$ & .00706662 \\
\hline Most Extreme & Absolute & .154 \\
\hline \multirow[t]{2}{*}{ Differences } & Positive & .084 \\
\hline & Negative & -.154 \\
\hline Test Statistic & & .154 \\
\hline Asymp. Sig. (2-tailed) & & $.200^{\mathrm{cd}}$ \\
\hline \multicolumn{3}{|c|}{ a. Test distribution is Normal. } \\
\hline \multicolumn{3}{|c|}{ b. Calculated from data. } \\
\hline \multicolumn{3}{|c|}{ c. Lilliefors Significance Correction. } \\
\hline \multicolumn{3}{|c|}{$\mathrm{d}$. This is a lower bound of the true significance. } \\
\hline
\end{tabular}

Berdasarkan hasil uji normalitas pada Tabel. 3 diatas dapat dilihat nilai Asymp. Sig. sebesar 0,200>0,05. Maka dapat disimpulkan bahwa data berdistribusi normal. Untuk lebih memperjelas tentang sebaran data dalam penelitian ini maka akan disajikan dalam grafik Normal P-Plot yang telah disajikan dalam Gambar 1. berdasarkan grafik Normal P-Plot dapat dilihat bahwa titik menyebar disekitar garis dan mengikuti arah garis diagonal, maka residual pada regresi tersebut berdistribusi secara normal. 


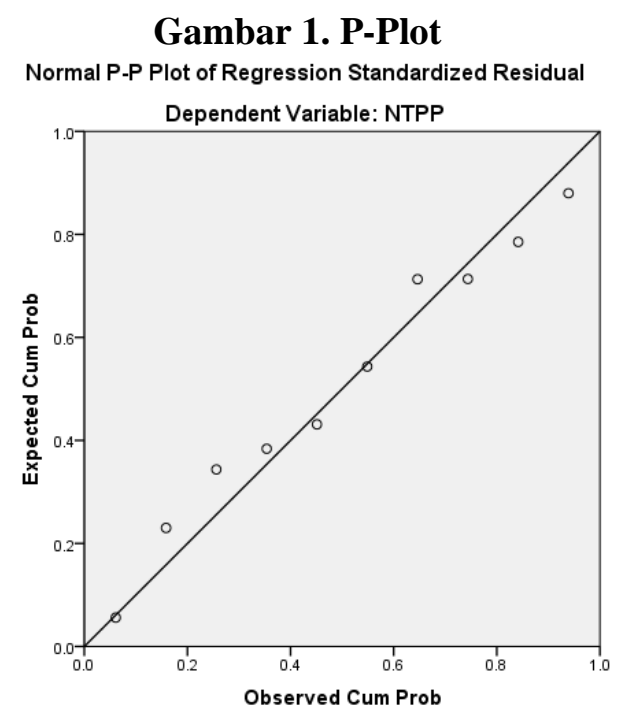

b. Uji multikolinieritas

Tabel. 4 Uji Multikolinieritas

\begin{tabular}{|c|c|c|c|}
\hline \multicolumn{4}{|c|}{ Coefficients $^{\mathbf{a}}$} \\
\hline & & \multicolumn{2}{|c|}{ Collinearity Statistics } \\
\hline Model & & Tolerance & VIF \\
\hline 1 & Tingkat Pengeluaran & .929 & 1.077 \\
\hline & Luas Panen & .894 & 1.119 \\
\hline & Impor Pangan & .834 & 1.199 \\
\hline a. Depe & ndent Variabel: NTPF & & \\
\hline
\end{tabular}

Berdasarkan tabel Coefficient menunjukkan nilai untuk tolerance untuk variabel tingkat pengeluaran $\left(X_{1}\right)$ sebesar 0,929>0,10, untuk variabel luas panen $\left(X_{2}\right)$ sebesar 0,894 >0,10 dan untuk variabel impor pangan sebesar 0,834 >0,10. Maka dapat disimpulkan bahwa tidak terjadi multikoliniearitas terhadap data yang diuji.

Sementara untuk nilai VIF variabel tingkat pengeluaran $\left(X_{1}\right)$ sebesar $1,077<10,00$, untuk variabel luas panen $\left(\mathrm{X}_{2}\right)$ sebesar 1,119<10,00 dan untuk variabel luas lahan $\left(\mathrm{X}_{3}\right)$ sebesar 1,199 $<10,00$. Maka dapat disimpulkan bahwa tidak terjadi multikoliniearitas terhadap data yang diuji.

\section{Uji Regresi Liner Berganda}

Hasil dari Uji regresi Liner Berganda dapat dlihat pada tabel dibawah ini :

Table.5 Uji regresi Liner Berganda

Coefficients $^{\mathrm{a}}$ 


\begin{tabular}{|c|c|c|c|c|c|c|}
\hline \multirow{3}{*}{$\begin{array}{l}\text { Model } \\
1\end{array}$} & & \multicolumn{2}{|c|}{$\begin{array}{l}\text { Unstandardized } \\
\text { Coefficients }\end{array}$} & \multirow{2}{*}{$\begin{array}{l}\text { Standardized } \\
\text { Coefficients } \\
\text { Beta }\end{array}$} & \multirow{3}{*}{$\begin{array}{c}\mathrm{t} \\
16.858\end{array}$} & \multirow{3}{*}{$\begin{array}{l}\text { Sig. } \\
\quad .000\end{array}$} \\
\hline & & B & Std. Error & & & \\
\hline & (Constant) & 2.203 & .131 & & & \\
\hline & $\begin{array}{l}\text { Tingkat } \\
\text { Pengeluaran }\end{array}$ & -.057 & .023 & -.390 & -2.475 & .048 \\
\hline & Luas Panen & .019 & .004 & .713 & 4.441 & .004 \\
\hline a. Depe & $\begin{array}{l}\text { Impor Pangan } \\
\text { ndent Variabel: }\end{array}$ & .020 & .009 & .378 & 2.273 & .063 \\
\hline
\end{tabular}

Berdasarkan tabel diatas, didapat persamaan regresi linier berganda sebagai berikut :

$$
\begin{aligned}
& \mathrm{Y}=\mathrm{a}+\mathrm{b} 1 \mathrm{x} 1+\mathrm{b} 2 \times 2+\mathrm{b} 3 \times 3+\mathrm{e} \\
& \mathrm{Y}=2.203-0,057 \mathrm{X}_{1}+0,019 \mathrm{X}_{2}+0,020 \mathrm{X}_{3}+\mathrm{e}
\end{aligned}
$$

Keterangan :

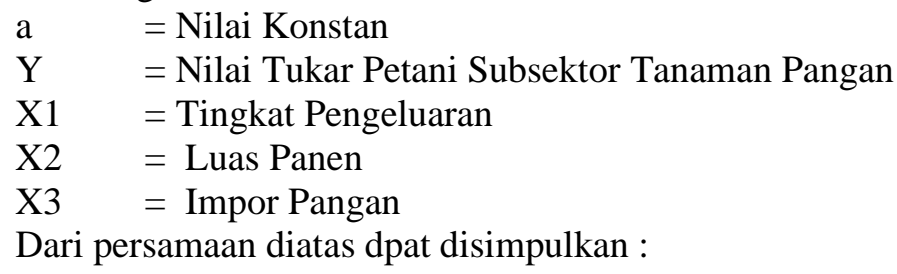

Dari persamaan diatas dpat disimpulkan :

a) Nilai Konstanta (a) sebesar 2,203. Yang artinya jika variabel tingkat pengeluaran, luas panen dan impor pangan sama dengan nol (0), maka nilai tukar petani subsektor tanaman pangan (Y) sebesar 2,203.

b) Koefisien Regresi Tingkat Pengeluaran $\left(\mathrm{X}_{1}\right)$ sebesar -0,057, menyatakan bahwa setiap penambahan 1 pengeluaran maka nilai tukar petani subsektor tanaman pangan terjadi penurunan sebesar $-0,057$. artinya terjadi hubungan negatif antara tingkat pengeluaran (X1) terhadap nilai tukar petani subsektor tanaman pangan $(\mathrm{Y})$.

c) Koefisien Regresi luas panen (X2) sebesar 0,019, menyatakan bahwa setiap penambahan tingkat produksi sebesar 1 maka nilai tukar petani subsektor tanaman pangan terjadi kenaikan sebesar 0,019, artinya terjadi hubungan positif antara luas panen (X2) terhadap nilai tukar petani subsektor tanaman pangan $(\mathrm{Y})$.

d) Koefisien Regresi impor pangan (X3) sebesar 0,020 menyatakan bahwa setiap pembahan impor sebesar 1 maka nilai tukar petani subsektor tanaman pangan akan naik sebesar 0,018. Artinya terjadi hubungan positif antara impor pangan (X3) terhadap nilai tukar petani subsektor tanaman panggan $(\mathrm{Y})$.

\section{Uji t (Parsial)}

Untuk melihat pengaruh variabel independen terhadap dependen, uji t dilakukan dengan membandingkan nilai $t_{\text {hitung }}$ dangan $t_{\text {tabel. }}$. Berikut hasil dari uji $t$ :

\begin{tabular}{|c|c|c|c|c|c|c|}
\hline \multicolumn{7}{|c|}{ Coefficients $^{\mathbf{a}}$} \\
\hline \multirow[b]{2}{*}{ Model } & \multirow[b]{3}{*}{ (Conotont) } & \multicolumn{2}{|c|}{$\begin{array}{l}\text { Unstandardized } \\
\text { Coefficients }\end{array}$} & \multicolumn{3}{|l|}{$\begin{array}{l}\text { Standardized } \\
\text { Coefficients }\end{array}$} \\
\hline & & B & Std. Error & Beta & $\mathrm{t}$ & Sig. \\
\hline 1 & & 2.203 & .131 & & 16.858 & .000 \\
\hline & $\begin{array}{l}\text { Tingkat } \\
\text { Pengeluaran }\end{array}$ & -.057 & .023 & -.390 & -2.475 & .048 \\
\hline
\end{tabular}

Tabel. 6 Uji Parsial (Uji t)

JURNAL ILMIAH KOMPUTERISASI AKUNTANSI Vol. 14, No. 2, Desember $2021: 383$ - 393 


\begin{tabular}{cccccc}
\hline Luas Panen & .019 & .004 & .713 & 4.441 & .004 \\
Impor Pangan & .020 & .009 & .378 & 2.273 & .063 \\
a. Dependent Variabel: NTPP & & & & &
\end{tabular}

Diketahui nilai tabel pada taraf signifikansi 5\% (2-tailed) dengan persamaan berikut :

Df $\quad=\mathrm{n}-\mathrm{k}-1 ;$ alpha/2

$$
\begin{aligned}
& =10-3-1: 0,05 / 2 \\
& =6: 0,025 \\
& =2,44691\left(\mathrm{t}_{\text {tabel }}\right)
\end{aligned}
$$

Keterangan :

$\mathrm{n} \quad=$ Jumlah

$\mathrm{k} \quad=$ Jumlah Variabel Bebas

$1=$ Konstan

Berdasarkan tabel output diatas, pengujian hipotesis dalam penelitian ini dapat dijabarkan sebagai berikut dengan nilai $t_{\text {tabel }}$ pada taraf signifikansi 5\% dan df (derajat kebebasan) atau $\mathrm{t}_{\text {tabel }} \mathrm{n}-\mathrm{k}-1=6$ adalah 2,44691 .

\section{Uji F (Simultan)}

Penelitian ini memakai tingkat signifikan $\alpha 0,05$ atau 5\%. Bila $\mathrm{F}_{\text {hitung }}>\mathrm{F}_{\text {tabel, }}$ maka Ha diterima, dan jika tingkat signifikan $<0,05$ maka Ha diterima. Adapun hasil dari Uji F (Simultan)

\begin{tabular}{|c|c|c|c|c|c|c|}
\hline \multicolumn{7}{|c|}{ ANOVA $^{\mathbf{a}}$} \\
\hline \multirow{3}{*}{$\begin{array}{l}\text { Model } \\
1\end{array}$} & & $\begin{array}{l}\text { Sum of } \\
\text { Squares }\end{array}$ & $\mathrm{df}$ & Mean Square & & \\
\hline & Regression & .003 & 3 & .001 & 12.476 & $.005^{\mathrm{b}}$ \\
\hline & Residual & .000 & 6 & .000 & & \\
\hline & Total & .003 & 9 & & & \\
\hline
\end{tabular}
sebagai berikut :

Tabel 7 Uji F (Simultan)

a. Dependent Variabel: NTPP

b. Prediktors: (Constant), Impor Pangan, Tingkat Pengeluaran, Luas Panen berikut :

Berdasarkan tabel diatas, diperoleh $\mathrm{f}_{\text {hitung }}$ sebesar 11,544 dan diperoleh $\mathrm{f}_{\text {tabel }}$ sebagai

$\mathrm{K}=$ jumlah variabel independen

$\mathrm{N}=$ jumlah responden atau sampel

$\mathrm{F}$ tabel $=\mathrm{k} ; \mathrm{n}-\mathrm{k}$

F tabel $=3 ; 10-3$

F tabel $=3 ; 7$

$\mathrm{F}$ tabel $=4,35$

Pada tabel diatas nilai $f_{\text {hitung }}(12.476)>f_{\text {tabel }}(4,35)$ dengan nilai signifikan sebesar 0,005 $<0,05$ menunjukkan bahwa variabel independen berpengaruh secara bersama-sama terhadap variabel dependen. artinya variabel tingkat pengeluaran, luas panen dan impor pangan berpengaruh secara simultan terhadap nilai tukar petani subsektor tanaman pangan di Provinsi Riau.

\section{Uji Koefisien Determinan ( $\mathbf{R}^{2}$ )}

Tabel 8.

Hasil Uji Determinasi Secara Simultan

Model Summary 


\begin{tabular}{|l|r|r|r|r|r|}
\hline \multirow{3}{*}{ Model } & \multicolumn{6}{|c|}{ Change Statistics } \\
\cline { 2 - 7 } & $\begin{array}{c}\text { R Square } \\
\text { Change }\end{array}$ & F Change & df1 & df2 & Sig. F Change \\
\hline 1 & $.862^{\mathrm{a}}$ & 12.476 & 3 & & .005 \\
\hline
\end{tabular}

a. Prediktors: (Constant), Impor Pangan, Tingkat Pengeluaran, Luas Panen

Berdasarkan tabel Model Summary, diperoleh nilai Adjust R2 sebesar 0,862 atau 86,2\%. Hal ini menunjukkan bahwa persentase sumbangan pengaruh variabel independen (tingkat pengeluaran, luas panen dan impor pangan) terhadap variabel dependen (nilai tukar petani) sebesar $86,2 \%$ sedangkan sisanya sebesar $13,8 \%$ dipengaruhi dan dijelaskan oleh variabel lain yang tidak dimasukkan dan dibahas dalam model penelitian ini.

\section{PEMBAHASAN}

\section{Pengaruh variabel Tingkat pengeluaran terhadap Nilai Tukar Petani Subsektor Tanaman Pangan}

Diketahui bahwa nilai $\mathrm{t}$ hitung $(-2,475)<\mathrm{t}$ tabel $(2,44691)$,dengan nilai signifikan sebesar $0,048<0,05$. Maka Ha diterima, artinya secara parsial ada pengaruh tingkat pengeluaran terhadap nilai tukar petani subsektor tanaman pangan Provinsi Riau. Hal ini menunjukkan bahwa tingkat pengeluaran berpengaruh signifikan terhadap nilai tukar petani subsektor tanaman pangan.

Adanya pengaruh negatif terhadap pengeluaran dikarenakan semakin tinggi tingkat pengeluaran yang dikeluarkan petani maka pendapatan yang diterima petani akan berkurang. Hasil penelitian ini juga sesuai dengan penelitian yang dilakukan oleh (Riyadh \& Ilham., 2015.) mengenai beberapa faktor yang menentukan nilai tukar petani dimana hasil penelitian menunjukkan bahwa pengeluaran komsumsi dan non-konsumsi berpengaruh secara negatif terhadap nilai tukar petani.

\section{Pengaruh variabel luas panen terhadap Nilai Tukar Petani Subsektor Tanaman Pangan}

Berdasarkan Uji statistic diketahui bahwa nilai $t_{\text {hitung }}(4,441)>t_{\text {tabel }}(2,44691)$,dengan nilai signifikan sebesar $0,004<0,05$. Maka Ha diterima, artinya secara parsial ada pengaruh luas panen terhadap nilai tukar petani subsektor tanaman pangan Provinsi Riau. hal ini menunjukkan bahwa luas panen berpengaruh terhadap nilai tukar petani subsektor tanaman pangan.

Luas lahan panen merupakan luas areal yang diambil hasilnya, yang berarti semakin luas areal panen maka semakin banyak pula hasil produksinya yang akan meningkatkan pendapatan petani sehingga kesejahteraan petani semakin meningkat.

Penelitian ini juga sejalan dengan toeri (Fadhilah, 2016.) bahwa luas lahan merupakan salah satu faktor utama dalam peningkatan produksi padi yang pada gilirannya juga bisa meningkatkan kesejahteraan petani padi.

\section{Pengaruh Impor Pangan terhadap Nilai Tukar Petani Subsektor Tanaman Pangan}

Diketahui bahwa nilai $\mathrm{t}_{\text {hitung }}(2.273)<\mathrm{t}_{\text {tabel }}(2,44691)$, dengan nilai signifikan sebesar 0,063 $>0,05$. Maka Ha ditolak, artinya secara parsial tidak berpengaruh signifikan antara impor pangan terhadap nilai tukar petani subsektor tanaman pangan Provinsi Riau. Hal ini menunjukkan bahwa impor pangan tidak berpengaruh terhadap nilai tukar petani subsektor tanaman pangan.

JURNAL ILMIAH KOMPUTERISASI AKUNTANSI Vol. 14, No. 2, Desember $2021: 383$ - 393 
Dalam penelitian ini secara parsial tidak ada pengaruh antara impor pangan terhadap nilai tukar petani subsektor tanaman pangan. Hal ini disebabkan beberapa faktor diantaranya adalah kecilnya cakupan wilayah dan hasil yang diproduksi dibandingkan dengan daerah dan provinsi lain. Sehingga dampak dari impor belum berpengaruh signifikan. Selain hal itu, berdasarkan wawancara yang dilakukan, diantara yang bertani padi maupun palawija sebagian besar digunakan untuk konsumtif rumah tangga. Sementara untuk produksi lebih akan dipasarkan di wilayah sekitar.

\section{Conclusion}

Tingkat pengeluaran berpengaruh negatif dan signifikan terhadap nilai tukar petani subsektor tanaman pangan, hal ini bisa dilihat dari nilai $t_{\text {hitung }}(-2,475)<t_{\text {tabel }}(2,44691)$ dengan nilai signifikan $0,048<0,05$. Luas panen berpengaruh positif secara signifikan terhadap nilai tukar petani subsektor tanaman pangan, hal ini bisa dilihat dari nilai $t_{\text {hitung }}(4,441)<\mathrm{t}_{\text {tabel }}(2,44691)$ dengan nilai signifikan $0,004<0,05$. Sementara untuk variabel impor pangan tidak berpengaruh signifikan terhadap nilai tukar petani subsektor tanaman pangan, hal ini bisa dilihat dari nilai $t_{\text {hitung }}$ $(2,273)<t_{\text {tabel }}(2,44691)$ dengan nilai signifikan 0,063 > 0,05. Tingkat pengeleluaran, luas panen dan impor pangan berpengaruh secara simultan terhadap nilai tukar petani subsektor tanaman pangan di Provinsi Riau, hal ini bisa dibuktikan dengan melihat nilai $F_{\text {hitung }}(12.476)$ lebih besar dari pada $\mathrm{F}_{\text {tabel, }}(4,35)$ dengan nilai signifikan sebesar $0,005<0,05$.

\section{References}

Fadhilah, N. (2016.). Analisis Faktor-Faktor Yang Mempengaruhi Nilai Tukar Petani Subsektor Tanaman Pangan Padi Di Aceh. Jurnal Ilmiah Mahasiswa (JIM) Ekonomi Pembangunan, Vol.1, No.1. .

Nirmala, A. R. (2016). “Analisis Faktor Faktor yang Mempengaruhi Nilai Tukar Petani Tanaman Pangan di Kabupaten Jombang. Jurnal Habitat Vol. 27.NO. 2.

Nono Rusono, (. (2013). Analisis Nilai Tukar Petani (NTP) Sebagai Bahan Penyusunan RPJMN Tahun 2015-2019. Kementerian Perencanaan Pembangunan Nasional/Bappenas Japan International Cooperation Agency (Jica).

Pratisto, A. (2016). Cara Mudah Mengatasi Masalah Statistik dan Rancangan Percobaan dengan SPSS 12. Jakarta.

Riau, B. P. (2017). Statistik Nilai Tukar Petani.

Riyadh, \& Ilham., M. (2015.). Analisis Nilai Tukar Petani Komoditas Tanaman Pangan Di Sumatera Utara. . Jurnal Ekonomi \& Kebijakan Publik, Vol. 6, No. 1.

Siregar, S. (2015). Metode Penelitian Kuantitatif : dilengkapi perbandingan perhitungan manual \& SPSS. Jakarta.

Sujarweni, W. (2016). Kupas Tuntas Penelitian Akuntasi Dengan SPSS. Yogyakarta: : Pustaka Baru Press. 